Original Article

\title{
Biodiversity of orb-web spiders (family: araneidae) of buner valley, Pakistan
}

\author{
Biodiversidade de aranhas construtoras de teia (família: araneidae) do vale buner, \\ Paquistão
}

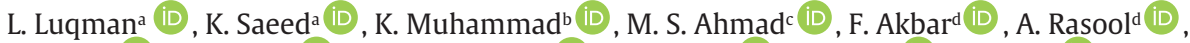

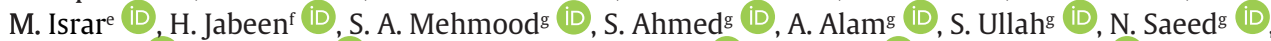

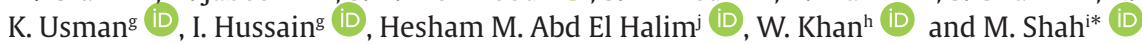
aDepartment of Zoology, University of Buner, Khyber Pakhtunkhwa, Pakistan

bDepartment of Genetics, Hazara University Mansehra, Khyber Pakhtunkhwa, Pakista

'Department of Zoology, University of Swabi, Khyber Pakhtunkhwa, Pakistan

¿Centre for Biotechnology \& Microbiology, University of Swat, Khyber Pakhtunkhwa, Pakistan

eDepartment of Forensic Sciences, University of Swat, Khyber Pakhtunkhwa, Pakistan

fDepartment of Microbiology, Women University Mardan, Khyber Pakhtunkhwa, Pakistan

'Department of Zoology, Hazara University Mansehra, Khyber Pakhtunkhwa, Pakistan

hDepartment of Zoology, University of Malakand, Chakdara, Khyber Pakhtunkhwa, Pakistan

${ }^{i}$ Centre for Animal Sciences \& Fisheries, University of Swat, Khyber Pakhtunkhwa, Pakistan

jDepartment of Entomology , Faculty of Science , Benha University , Benha , 13518, Egypt

\begin{abstract}
The present research was carried out to explore the spider fauna of Buner valley with taxonomic study from February 2018 to January 2019. For this purpose samples were collected, four times at each month from 4 tehsils: Daggar, Gagra, Mandan and Totalai. Two methods were used, hand picking and sweep net for collection of samples. During day and night, three habitats, arid area, agriculture land and building area were search for collection. A total of 534 samples of spider were collected from four sampling sites, in which 379 were belonging to family Araniedae. After confirmation, the identified species were belonging to 8 genera (Neoscona, Argiope, Cyclosa, Araneus, Cyrtophora, Larinia, Erivoxia and Poltys) and 19 species. 18 of them were identified to specie level while a single specie to its generic level. The genus Neoscona was the dominant genus $26.31 \%$ having 5 species while the genus Argiope $21.05 \%$ is the second dominant having 4 species followed by Cyclosa $15.78 \%$ having 3 species followed by Cyrtophora and Araneus 10.52\% having two species both. The Poltys and Larinia 5.26\% are the rarest genera represent single-single specie both. Statistical analysis show that specie richness (D) $=5.77$, Simpson index (1-D) $=0.87$, Shannon index $(H)=2.33$. Diversity of spiders was evenly distributed and calculated Evenness value was $\mathrm{H} / \mathrm{InS}=0.5408$. There is also few atypical species and Fisher alpha estimate high value (Fisher $\alpha)=4.42$. Chao- 1 estimated we have reported 22 species.
\end{abstract}

Keywords: diversity, orb-web spider, Araneidae, Buner, Pakistan.

\begin{abstract}
Resumo
A presente pesquisa foi realizada para explorar a fauna de aranhas do vale Buner, em um estudo taxonômico realizado de fevereiro de 2018 a janeiro de 2019. Para esse fim, foram coletadas amostras, quatro vezes por mês, a partir de 4 subdistritos: Daggar, Gagra, Mandan e Totalai. Foram utilizados dois métodos, coleta manual e rede de varredura, para a obtenção das amostras. Durante o dia e a noite, foram pesquisados três habitats: área árida, área agrícola e área de construção. Foram coletadas 534 amostras de aranha em quatro locais de amostragem, sendo que 379 pertenciam à família Araneidae. Após a confirmação, as espécies identificadas pertenciam a 8 gêneros (Neoscona, Argiope, Cyclosa, Araneus, Cyrtophora, Larinia, Erivoxia e Poltys) e a 19 espécies (18 delas foram identificados em seu nível de espécie, enquanto uma única foi identificada em seu nível genérico). O gênero Neoscona foi dominante (26,31\%), com 5 espécies, seguido pelos gêneros Argiope (21,05\%), com 4 espécies, Cyclosa (15,78\%), com 3 espécies, e Cyrtophora e Araneus (10,52\%), com 2 espécies. Poltys e Larinia (5,26\%) são os gêneros mais raros, representando a mesma espécie. A análise estatística mostrou que a riqueza de espécies (D) foi de 5,77, o índice de Simpson (1-D) foi de 0,87 e o índice de Shannon $(\mathrm{H})$ foi de 2,33. A diversidade de aranhas foi distribuída uniformemente, e o valor calculado da uniformidade foi $\mathrm{H} / \mathrm{InS}=0,5408$. Também existem poucas espécies atípicas, e o alfa de Fisher (Fisher $\alpha$ ) estimou o valor de 4,42. Já Chao-1 estimou 22 espécies.
\end{abstract}

Palavras-chave: diversidade, aranhas construtoras de teia, Araneidae, Buner, Paquistão.

*e-mail: muzafar@uswat.edu.pk

Received: May 20, 2020 - Accepted: July 28, 2020

This is an Open Access article distributed under the terms of the Creative Commons Attribution License, which permits unrestricted use, distribution, and reproduction in any medium, provided the original work is properly cited. 


\section{Introduction}

Spiders (Order; Araneae) are the great evolutionary success group of Arthropoda, belonging to class Arachnida (Miller and Sac, 2011). The presence of pedicel makes the spider alike from other arachnids. The body of spider consists of cepalothorax which have eight appendages of legs, two appendages of padipalps, male reproductive organ, sensory organs and the abdomen having the female reproductive organ and spinnerets at the posterior tip of the abdomen, for the secretion of silk (Sebastian and Peter, 2009). Spider are the most diverse group of animal attending the seventh position in diversity containing 46,438 species under 3,905 genera belonging to 114 families. The diversity and abundance of spider depend on both biotic and abiotic factors. The vegetation, availability of preys are the biotic factor and temperature, humidity, shelter, and seasonal changes are the abiotic factor which effect the abundance and diversity of spider. The diversity and abundance are also affected by human activities such as overpopulation, urbanization and different pesticides (Tanaka, 1989; Wise, 1995; Halaj et al., 1998; Sorensen, 2004; Suana, 2005; Foelix, 2011).

Family Araneidae are commonly known is Orb-weavers are the most cosmopolitan group of spider. They built spiral wheel shaped webs and are mostly found in grasslands, gardens, crops and forests. Orb-web weavers have eight similar eyes arrange in two rows, eight legs with spines or hair and do not have stridulating organ. They are mostly bright in color, large sized and three claws spiders. Orb-web weavers are ranking in third in the diversity; consist of 3122 species fewer than 172 genera (Levi et al., 2002). The spiders are totally polyphagous carnivores and feed on the different variety of prey, not only on adult they feed on all stages of preys such as eggs and larvae. They play a great role in controlling of pest and as a good friend of farmers (Marc et al., 1999). They are also good biological indicator (Marc et al., 1999; Pearce and Venier, 2006). The silk of spider are also economically important and used in different strategies (Sebastian and Peter, 2009). Pakistan is proper country for the survival of different fauna because of their different weather, rang of temperature and geological areas so there is a rich fauna of spider but still now the total fauna of spider are unknown. However some work on spider fauna of different habitat are documented by (Butt and Beg, 2000, 2001; Ghafoor and Beg, 2002; Mukhtar and Mushtaq, 2005b; Hennawy, 2009; Ursani and Soomro, 2010; Tahir et al., 2011). In different ecosystem the pest of varies stages controlling activity of spider were documented by (Butt and Beg, 2001; Wise, 1993). Predatory effect and diversity of spider in rice and brassica field of Punjab were documented by Tahir and Butt 2009 and Mukhtar et al., 2012. Parveen et al., 2007 well documented the spider fauna of Punjab and listed 157 species belonging to 56 genera under 21 families. Shirbhate and shirbhate, (2017) explore the diversity of family Araneidae in India. The spider fauna of KP were documented by Khan and Zaman, (2015) \& Ahmad et al., (2015). However, the total fauna of spiders and especially family Araneidae is more needed to be discovered.

\section{Methodology}

\subsection{Study area}

District Buner is located in Malakand agency Khyber Pakhtunkhwa province of Pakistan. The total area of Buner is $1,865 \mathrm{~km}^{2}\left(720 \mathrm{mile}^{2}\right)$ and its total population is 897,319 with the density of population $480 / \mathrm{km}^{2}$ or $1,200 / \mathrm{mile}^{2}$. District Buner share their boundaries with district Mardan on south, on west with Malakand agency, on north with district swat, on east with Hazara Division. The area of Buner are Sub tropical mountain area and there are five different types of habitats which are arranged in irregular pattern. These habitats are Agricultural area, woody ravines area, shrubs land, slopes of grass and mountain and Barren rocks.

\subsection{Study design}

Specimens were collected from four sites, Daggar, Gagra, Mandanr, and Totalai. Visits were made each sites four time, first visit at January, second at March, third at June and the last visit at September. Samples were collected during day (9:00am-4:00pm) and night time (7:00pm-11:00pm). Collection site was agriculture lands (Crops of wheat, maize, sugar cane, and some vegetables), fruit gardens (Orange and peach plants), building (houses, bathroom and from walls).

\subsection{Ecological indices}

To calculate ecological diversity of Orb-web spiders the following ecological indices were used (Tahir, Butt, 2009). Species richness (D):

$$
\mathrm{D}=(\mathrm{S}-1) / \ln (\mathrm{N})
$$

Where: $\mathrm{D}=$ Species richness, $\mathrm{S}=$ Number of species, $\mathrm{N}=$ Number of individuals.

Fisher's alpha ( $\alpha$-Fisher):

$$
\text { Fisher's } \alpha=\alpha \ln (1+\mathrm{N} / \alpha)
$$

Where: $\mathrm{S}=$ Number of species in the sample, $\mathrm{N}=$ Number of individuals in the sample and $\alpha=$ Diversity coefficient. Shannon Diversity Index:

$$
\left(\mathrm{H}^{\prime}\right)=-\Sigma(\text { pi ln pi })
$$

Where $\mathrm{pi}$ = proportional frequency of the species (Magurran, 1988).

Evenness Index $(\mathrm{E})$ :

$$
\mathrm{E}=\mathrm{H}^{\prime} / \ln (\mathrm{S})
$$

Where H' is the Shannon Diversity Index and S is the number of species.

\subsection{Identification}

Identification was done by using a stereo microscope (XTD-2A china) to study different organs of the spiders in laboratory at the Department of Zoology, University of Buner. The collected specimens were identified by available keys (Tikader and Malhotra, 1980; Tikader and Biswas, 1981; Tikader, 1987). 


\section{Results and Discussion}

The current study was conducted during February 2018 to last January 2019. A total of 534 specimens of spider were handover from four sampling sites, 379 of them were belonging to family Aranidae. 321 samples were while remaining are young's and unidentified. The identified species belong to 8 genera (Neoscona, Argiope, Cyclosa, Araneus, Cryptophora, Larinia, Erivoxia, Poltys) and 19 species. 18 of them were identified to specie level while a single specie to its generic level (Figure 1). The genus Neoscona was the dominant genus $26.31 \%$ having 5 species while the genus Argiope $21.05 \%$ is the second dominant having 4 species followed by Cyclosa $15.78 \%$ having 3 species followed by Cyrtophora and Araneus $10.52 \%$ having two species both. The Poltys 5.26\% and Larinia 5.26\% are the rarest genera represent single-single specie both. Diversity indices were calculated, show specie richness $(D)=5.77$, Simpson index $(1-D)=0.87$, Shannon index $(H)=2.33$. The spider fauna of current study area are evenly distributed and having value of Evenness $\mathrm{H} / \mathrm{InS}=0.5408$. There is also some rare species and Fisher alpha estimate high value $($ Fisher $\alpha)=4.42$. Chao- 1 estimated we have reported 3 more species. Daggar was the most specie richest site during the present research having specie richness value $(D)=3.04$ followed by Totalai $(D)=2.52$ while the lowest (D) value was recorded in Mandanr. In each there was evenly distributed but the highest value of evenness $\mathrm{H} / \mathrm{InS}=0.75$ followed by Totalai $(0.73)$ while the lowest value of evenness was (0.66) in Daggar (Figure 2). Diversity index of each sites were calculated, the highest value of diversity index were record in Daggar, $\mathrm{H}=2.23$ and $(1-\mathrm{D})=0.87$ followed by Mandanr, $\mathrm{H}=2.11$ and $(1-\mathrm{D})=0.86$ greater than Totalai $\mathrm{H}=2.09$ and $(1-\mathrm{D})=0.84$ while the lowest value recorded in Gagra, $\mathrm{H}=2.00$ and $(1-\mathrm{D})=0.82$ (Table 1 ). Genus Neoscona is the most dominant genus (26.31\%) representing 5 species and are abundant in study sites. Neoscona theisi (Walckenaer, 1841) are the most dominant specie (Total no 65) which was collected in a great number from all sampling sites while the Neoscona adianta (Walckenaer, 1802) are the second dominant abundant specie (total no 23) collected from all sampling sites, except Totalai. Neoscona crucifera (Lucas, 1839) are the median abundant specie (total no 9) and sampled from two sampling sites. Neoscona arabesca (Walckenaer, 1841) and Neoscona oaxacensis (Keyserling, 1863) are most rare species (total no 2, 1 respectively) from single single sampling sites. Most samples were collected from orchards and trees. Genus Argiope are the second dominant genus (21.05\%) representing 4 species but less in quantity. The Argiope pulchella (Thorell, 1881) are the abundant specie (Total no 5) from two sampling sites followed by Argiope aemula (Walckenaer, 1842) (Total no 3) from two sites while the Argiope trifasciata (Forskal, 1775) and Argiope lobata (Pallas, 1772) are the very rare (total no 1,1) from single, single sites. Mostly they were collected from trees. Argiope were followed by Cyclosa representing 3 species (15.78\%). Cyclosa insulana (Costa 1834) (Total no 53) are the most abundant specie in all sampling sites during start summer while the Cyclosa conica (Pallas, 1772)(total no 19) are second dominant specie and Cyclosa bifida (Doleschall, 1859) (Total no 3) are the most rare species collected from single sampling site.
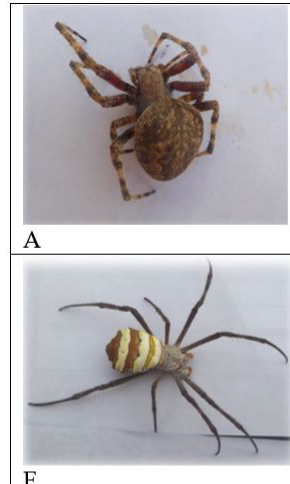

F

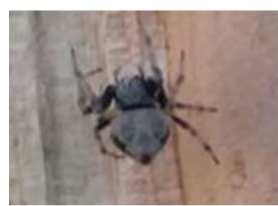

K

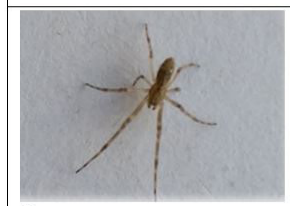

$\mathrm{P}$

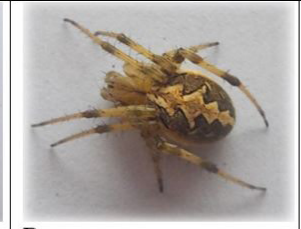

B
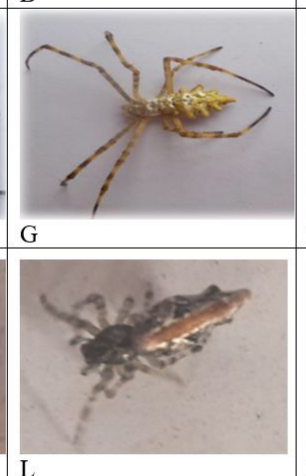

L

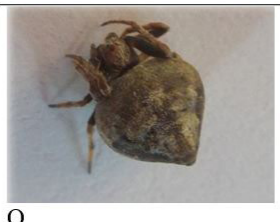

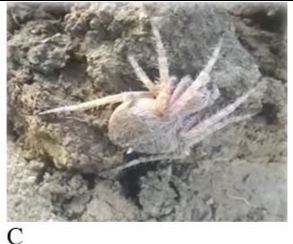

C

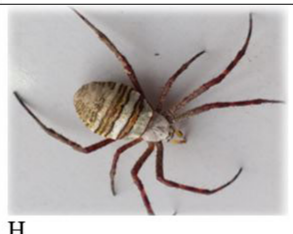

H

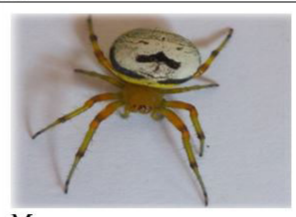

M

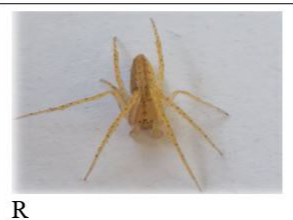

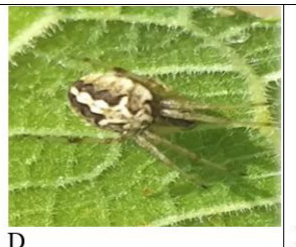

D
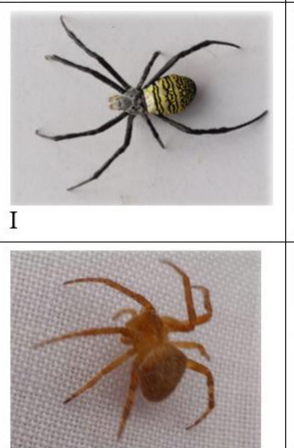

$\mathrm{N}$

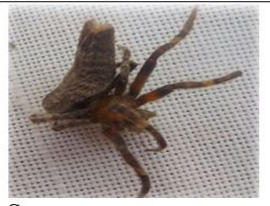

S
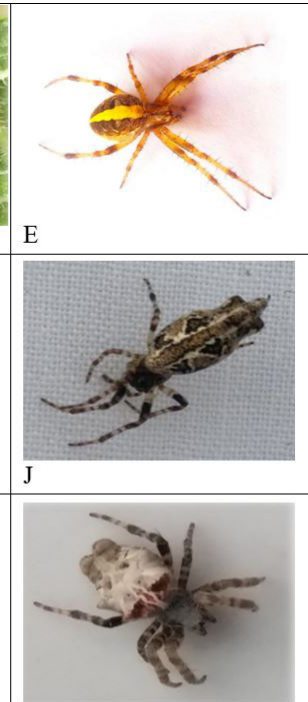

O

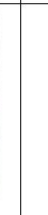

Figure 1. Species collected from the study area are A: Neoscona theisi ;B: Neoscona adianta ; C: Neoscona.crucifera ; D: Neoscona arabesca ; E: Neoscona oaxacensis ; F: Argiope pulchella ; G: Argiope lobata ; H: Argiope trifasciata; I: Argiope aemula ; J: Cyclosa insulana ; K: Cyclosa conica; L: Cyclosa bifida; M: Araneus mitificus; N: Araneus ellipticus; O: C.citricola; P: C.cicatorsa; Q: E.excelsa; R: L.chloris; S: Poltys spider. 

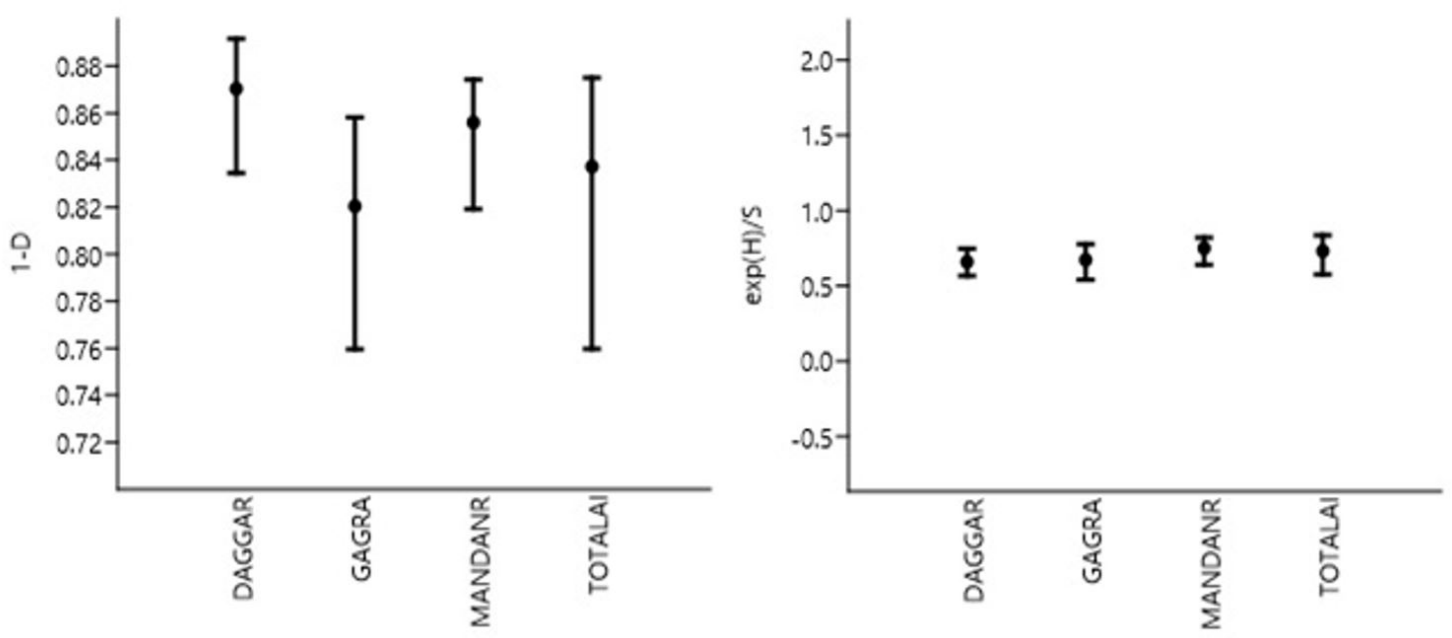

Figure 2. Simpson index (1-D) and Evenness H/InS.

Table 1. Table showing show statistical analysis of study sites.

\begin{tabular}{cccccccccc}
\hline S.No & Study sites & $\begin{array}{c}\text { Specie } \\
\text { richness (D) }\end{array}$ & $\begin{array}{c}\text { Simpson } \\
\text { index (1-D) }\end{array}$ & $\begin{array}{c}\text { Shannon } \\
\text { index (H) }\end{array}$ & Evenness & Equitability & $\begin{array}{c}\text { Fisher- } \\
\text { alpha }\end{array}$ & Chao-1 & Dominance \\
\hline 1 & Daggar & 3.04 & 0.8704 & 2.292 & 0.6597 & 0.8464 & 4.894 & 16 & 0.1296 \\
2 & Gagra & 2.362 & 0.8204 & 2.002 & 0.6729 & 0.8348 & 3.691 & 11 & 0.1796 \\
3 & Mandanr & 2.176 & 0.856 & 2.111 & 0.7506 & 0.8804 & 3.166 & 11 & 0.144 \\
4 & Totalai & 2.519 & 0.8373 & 2.085 & 0.7315 & 0.8696 & 4.219 & 11.5 & 0.1627 \\
\hline
\end{tabular}

Genus Araneus 10.52\% and genus Cryptophora 10.52\% both representing 2 species each, Araneus mitificus (Simon, 1886) (total no 26) are abundant specie of Araneus in all four sampling sites while Araneus ellipticus (Tikader and Bai, 1981) (Total no 9) are the less abundant of this genus collected from orchards and small plants. Cryptophora citricola (Forskal, 1775) (Total no 61) are most abundant specie sampled from all sampling sites; mostly they are seen in trees and live in colonies. The Cryptophora cicatrosa (Stoliczka, 1869) (total no 7) are the rare one of this genus. Genus Erivoxia 5.26\%, Larinia 5.26\% and poltys 5.25\% were the rare genus of this family in district Buner representing single, single specie each. Erivoxia excelsa (Simon, 1889) (Total no 11) collected from two sampling sites, while Larinia chloris (Audouin, 1826) (Total no 21) were hand over from all sampling sites. Genus poltys (Koch, 1843) are the rarest genus representing a single specie poltys spp (Total no 1 and single individual and would identify to its generic level (Table 2). Bultman and Uetz (1982) exposed that diversity and abundance of spider is prejudiced by environmental factors. The physiological tolerances ranges of temperature and humidity are restrictive factors that inhibit spider's diversity and abundance. Tews et al. (2004) concluded that habitat organization and vegetation type influence spiders diversity while the degradation of habitat may cause species extinction. Specie richness and composition of spiders is related with habitat structure and complexity of vegetation (Warghat et al., 2010; Lubin, 1978; Jiménez-Valverde and Lobo,
2007) while(Subrahmanyam, 1968; Corey et al., 1998; Pandit and Ik, 2017) stated that spider abundance in varies seasons is due to varies prototype of behavior of individual spider and morphology of spider community. Height of vegetation is highly significant for the webbed spiders (Uetz, 1975; Greenstone, 1984; Green, 1999). Monsoon is highly significant for the population of Araneidae due to height of vegetation. Generally we also observed the same situation during our study. We agree with Rodrigues et al. (2015), Rodrigues et al. (2015) revealed that Orb-web spiders are highly abundant in shrub-tree stratum, boundaries of grasslands and forests, required definite microclimates for web construction and gap for territory. Our report also agreement with (Miyashita, 1997) that cyclosa species favored to erect its web in forest edges near the floor of forests. The distinguish feature of Neoscona spiders is different abdominal pattern and groove on carapace longitudinally, 81 species of Neoscona spiders were reported worldwide (Platnick et al., 2014), chosen areas having high prey density (Adams, 2000). Generally we believe that these spiders are abundant in crops, orchards and forests, build wed less than a meter to 2 meter above the ground at late evening. Argiope spiders are notorious for conspicuous pattern on their abdomen and its web with crisscross figure, worldwide 76 species are reported until now (Platnick et al., 2014). We recorded that genus Argiope was the second dominant in specie richness, tolerate low temperature is compare to other spiders; construct wed on bushes, shrubs and trees. Genus Poltys was the rarest genus 
Table 2. Different species of spider collected from four sites: Site 1: Daggar, Site 2: Gagra, Site 3: Mandan and Site 4: Totali.

\begin{tabular}{|c|c|c|c|c|c|c|}
\hline S.No & Specie name & Site 1 & Site 2 & Site 3 & Site 4 & Total \\
\hline 1 & N. theisi (Walckenaer, 1841) & 23 & 18 & 21 & 3 & 65 \\
\hline 2 & N. adianta (Walckenaer, 1802) & 10 & 4 & 9 & 0 & 23 \\
\hline 3 & N. crucifera (Lucas, 1839) & 6 & 0 & 0 & 3 & 9 \\
\hline 4 & N. arabesca (Walckenaer, 1841) & 0 & 0 & 2 & 0 & 2 \\
\hline 5 & N. oaxacensis (Keyserling, 1863) & 1 & 0 & 0 & 0 & 1 \\
\hline 6 & A.pulchella (Thorell, 1881) & 3 & 0 & 0 & 2 & 5 \\
\hline 7 & A.lobata (Pallas, 1772) & 1 & 0 & 0 & 0 & 1 \\
\hline 8 & A.trifasciata (Forskal, 1775) & 0 & 0 & 1 & 0 & 1 \\
\hline 9 & A.aemula (Walckenaer, 1841) & 2 & 1 & 0 & 0 & 3 \\
\hline 10 & C.insulana (Costa, 1834) & 13 & 2 & 21 & 17 & 53 \\
\hline 11 & C.conica (Pallas, 1772) & 6 & 5 & 5 & 3 & 19 \\
\hline 12 & C.bifida (Dolescsall, 1859) & 3 & 0 & 0 & 0 & 3 \\
\hline 13 & A.mitificus (Simon, 1886) & 8 & 4 & 9 & 5 & 26 \\
\hline 14 & A.ellipticus (Tikader and Bai, 1981) & 2 & 2 & 4 & 1 & 9 \\
\hline 15 & C.citricola (Forskal, 1775) & 18 & 20 & 16 & 7 & 61 \\
\hline 16 & C.cicatorsa (Stoliczka, 1869) & 0 & 2 & 4 & 1 & 7 \\
\hline 17 & E.excelsa (Simon, 1889) & 0 & 5 & 0 & 6 & 11 \\
\hline 18 & L.chloris (Audouin, 1826) & 3 & 6 & 7 & 5 & 21 \\
\hline \multirow[t]{2}{*}{19} & Poltys Spps (C.L.Koch, 1843) & 1 & 0 & 0 & 0 & 1 \\
\hline & Total Species=19 & 100 & 69 & 99 & 53 & 321 \\
\hline
\end{tabular}

during current study collect from tall trees while Larinia on back side of leaves near the web. Diversity and distribution of Spider fauna (Family: Araneidae) in and around Katepurna Sanctuary, Akola, India show that Neoscona was the numerically predominant genus having 9 species (34.61\%), followed by Cyclosa (11.53\%) and Larinia (11.53\%) (Shirbhate and Shirbhate, 2017) while the present study the neoscona was the dominant genus having 5 species (26.31\%) followed by genus Argiope having 4 species (21.05\%). Ahmad et al. (2015) listed spider fauna of Buner valley having only three species of family Aranidae namely Neoscona theisi, Argiope aatikai and Neoscona crucifera while the present study 19 species of family Aranidae were reported, the two of them Neoscona theisi and Neoscona crucifera are reported in the present research while Argiope aatikai do not found. Khan and Zaman, (2015) reported 12 species from Pir baba District Buner in which family Aranidae are totally absent but however in the present work somewhat fauna of family Aranidae were reported. During the current study a total of 534 samples of spider were collected from four sampling sites, 379 of that were belonging to family Araniedae. 320 samples were identified to its species level, one sample to its generic level while remaining are young and unidentified species. Identified species were belonging to 8 genera (Neoscona, Argiope, Cyclosa, Araneus, Cyrtophora, Larinia, Erivoxia and Poltys) and 19 species. 18 of them were identified to specie level while a single specie to its generic level.

\section{Acknowledgements}

We are thankful to University of Buner and University of Swat for providing lab facilities during our research work.

\section{References}

ADAMS, M.R., 2000. Choosing hunting sites: web site preferences of the orb weaver spider, Neoscona crucifera,relative to light cues. Journal of Insect Behavior, vol. 13, no. 3, pp. 299-305. http://dx.doi.org/10.1023/A:1007771332721.

AHMAD, S., AKHTAR, N. and SAEED, K., 2015. Some observations on spider fauna of district. Buner: Department of Zoology, University of Buner, 55 p. MSc thesis in zoology.

BULTMAN, T.L. and UETZ, G.W., 1982. Abundance of spider community structure of forest floor spiders following litter manipulation. Oecologia, vol. 55, no. 1, pp. 34-41. http://dx.doi. org/10.1007/BF00386715. PMid:28309899.

BUTT, A. and BEG, M.A., 2000. Some new species of Marpissa (Salticidae) from Pakistan. Pakistan Journal of Zoology, vol. 32, pp. 75-79.

BUTT, A. and BEG, M.A., 2001. Description of two new species ofspiders of the families Clubionidae and Oxyopidae from Pakistan. Pakistan Journal of Zoology, vol. 33, pp. 35-37.

COREY, D.T., STOUT, I.J. and EDWARDS, G.B., 1998. Ground surface spider fauna in Florida sandhill communities. The Journal of Arachnology, vol. 26, no. 3, pp. 303-316. 
FOELIX, R., 2011. Biology of spiders. New York: Oxford University Press, pp. 1-344.

GHAFOOR, A. and BEG, M.A., 2002. Description of two new species of Araneid spiders from Pakistan. International Journal of Agriculture and Biology, vol. 4, pp. 525-527.

GREEN, J., 1999. Sampling method and time determines composition of spider collections. The Journal of Arachnology, vol. 27, no. 1, pp. 176-182.

GREENSTONE, M.H., 1984. Determinants of web spider species diversity. Vegetation structural diversity is prey availability. Oecologia, vol.62, no. 3, pp. 299-304. http://dx.doi.org/10.1007/ BF00384260. PMid:28310881.

HALAJ, J., DARRELL, W.R. and MOLDENKEL, A.R., 1998. Habitat structure and prey availability as predictors of the abundance and community organization of spiders in western Oregon forest canopies. The Journal of Arachnology, vol. 26, pp. 203-220.

HENNAWY, H.K., 2009. Eresidae of Sudan (Araneida: eresidae). Serket, vol. 11, pp. 129-137.

JIMÉNEZ-VALVERDE, A. and LOBO, J.M., 2007. Determinants of local spider (Araneidae and Thomisidae) species richness on a regional scale: climate and altitude vs. habitat structure. Ecological Entomology, vol. 32, no. 1, pp. 113-122. http://dx.doi. org/10.1111/j.1365-2311.2006.00848.x.

KHAN, J. and ZAMAN, A., 2015. Biodiversity of spider fauna in Pir Baba, District Buner, Khyber Pakhtunkhwa, Pakistan. Journal of Entomology and Zoology Studies, vol. 3, no. 1, pp. 69-74.

LEVI, H.W., LEVI, L.R., ZIM, H.S. and STREKALOVSKY, N., 2002. Spiders and Their Kin. New York: Golden Books Publishing Company, pp. 1-220.

LUBIN, Y.D., 1978. Seasonal abundance and diversity of web building spiders in relation to habitat structure on Barro Colorado I Panama. The Journal of Arachnology, vol. 6, no. 1, pp. 31-51.

MAGURRAN, A.E., 1988. Ecological diversity and its measurements. London: Croom Helm Limited, pp. 1-179. http://dx.doi. org/10.1007/978-94-015-7358-0.

MARC, P.A., CANARD, A. and YSNEL, F., 1999. Spiders (Araneae) useful for pest limitation and bioindication. Agriculture, Ecosystems E'Environment, vol. 74, no. 1-3, pp. 229-273. http:// dx.doi.org/10.1016/S0167-8809(99)00038-9.

MILLER, J.A. and SAC, P.D., 2011. Landscape biodiversity of tropical forest Spider communities in Vietnam (Arachnida: araneae). Treubia, vol. 38, pp. 53-70.

MIYASHITA, T., 1997. Factors affecting the difference in foraging success in three co-existing Cyclosa Spiders. Journal of Zoology, vol. 242, no. 1, pp. 137-149. http://dx.doi. org/10.1111/j.1469-7998.1997.tb02935.x.

MUKHTAR, M.K. and MUSHTAQ S., 2005b. Spiders of the Genus Cyclosa (Araneae: Araneidae) from Punjab, Pakistan. Pakistan Journal of Zoology, vol. 37, pp. 199-204.

PANDIT, R. and IK, P., 2017. Spiders of Taleigao Plateau, Goa, India. Journal of Environmental Science and Public Health USA, vol. 1, no. 4, pp. 240-252. http://dx.doi.org/10.26502/ jesph.96120022.

PLATNICK, N.I., BERNIKER, L. and VÍQUEZ, C., 2014. A new goblin spider genus of the Zyngoonops group from Costa Rica, with notes on Coxapopha (Araneae, Oonopidae). American Museum Novitates, vol. 3820, no. 3820, pp. 1-20. http://dx.doi. org/10.1206/3820.1.

PEARCE, J.L. and VENIER, L.A., 2006. The use of ground beetles (Coleoptera: Carabidae) and spiders (Araneae) as bioindicators of sustainable forest management: a review. Ecological Indicators, vol.6, no. 4, pp. 780-793. http://dx.doi.org/10.1016/j.ecolind.2005.03.005.
RODRIGUES, E.N., MENDONÇA JUNIOR, M.D.S., RODRIGUES, P.E. and OTT, R., 2015. Diversity, composition and phenology of araneid orb-weavers (Araneae, Araneidae) associated with riparian forests in southern Brazil. Iheringia. Série Zoologia, vol. 105, no. 1, pp. 53-61. http://dx.doi.org/10.1590/1678-4766201510515361.

SEBASTIAN, P.A. and PETER, K.V., 2009. Spiders of India. Hyderabad: Universities Press, pp. 1-15.

SHIRBHATE, M.V. and SHIRBHATE, A.M., 2017. Diversity and distribution of spider fauna (Family; Araneidae) in and around katepura sauntuary, Akota, India. Environment Conservation Journal, vol. 18, no. 3, pp. 45-52. http://dx.doi.org/10.36953/ECJ.2017.18306.

SøRENSEN, L.L., 2004. Composition and diversity of the spider fauna in the canopy of a montane forest in Tanzania. Biodiversity and Conservation, vol. 13, pp. 437-452. http://dx.doi.org/10.1023/ B:BIOC.0000006510.49496.1e.

SUANA, I.W., 2005. Bioecology of spiders in ricefield landscape at Cianjur. West Java. Bogor, Indonesia: School of Post Graduate Studies, Bogor Agricultural University, 128 p. Master Dissertation in Zoology.

SUBRAHMANYAM, T.V., 1968. An Introduction to the study of Indian spiders. Bombay Natural History Society, vol. 65, no. 2, pp. 453-461.

TAHIR, M. and BUTT, A., 2009. Some new species of family Lycosidae from agricultural fields of Punjab, Pakistan. Pakistan Journal of Zoology, vol. 38, pp. 185-189.

TAHIR, M.H., BUTT, A., NAHEED, R., BILAL, M. and ALAM, I., 2011. Activity density of spiders inhabiting the citrus field in Lahore, Pakistan. Pakistan Journal of Zoology, vol. 43, no. 4, pp. 683-688.

TANAKA, K., 1989. Movement of the spiders in arable land. Plant Protection, vol. 43, pp. 34-39.

TEWS, J., BROSE, U., GRIMM, V., TIELBORGER, K., WICHMANN, M.C., SCHWAGER, M. and JELTSCH, F., 2004. Animal species diversity driven by habitat heterogeneity/diversity: the importance of keystone structures. Journal of Biogeography, vol. 31, no. 1, pp. 79-92. http://dx.doi.org/10.1046/j.03050270.2003.00994.x.

TIKADER, B.K. and BISWAS, B., 1981. Spider fauna of Calcutta and vicinity part-I. Records of the Zoological Survey of India, vol. 30, pp. 1-148.

TIKADER, B.K. and MALHOTRA, M.S., 1980. Fauna of India, Araneae. Spiders, vol. 1, pp. 248-447.

TIKADER, B.K. (1987). Handbook of Indian Spiders (pp. 1-251). Kolkata: Zoological Survey of India.

UETZ, G.W., 1975. Temporal and spatial variation in species diversity of wandering spiders (Araneae) in deciduous forest litter. Environmental Entomology, vol. 4, no. 1, pp. 719-724. http:// dx.doi.org/10.1093/ee/4.5.719.

URSANI, T.J. and SOOMRO, N.M., 2010. Checklist of spider fauna of Sindh Province, Pakistan. Pakistan Journal of Entomology, vol. 32, no. 1, pp. 20-25.

WARGHAT, N.E., SARMA, N.R., CHIRDE, S.G. and CHANDRASEKAR, M.R., 2010. Distribution of spiders from foot hill agricultural fields of Satpura mountain range of Amravati district, Maharashtra, India. Bioscience Biotechnology Research Communications, vol. 3, no. 2, pp. 150-153.

WISE, D.H., 1993. Spiders in ecological webs. Cambridge: University Press, pp. 280-289. http://dx.doi.org/10.1017/CBO9780511623431.

WISE, D.H., 1995. Spiders in ecological webs. Cambridge: Cambridge University Press, pp. 119-125. 